\title{
The Associations Between Smoking Habits and Serum Triglyceride or Hemoglobin A1c Levels Differ According to Visceral Fat Accumulation
}

\author{
Michiko Koda ${ }^{1,2}$, Itsuko Kitamura ${ }^{2,3}$, Tomohiro Okura ${ }^{2,4}$, Rei Otsuka ${ }^{2}$, \\ Fujiko Ando ${ }^{2,5}$, and Hiroshi Shimokata ${ }^{2,6}$ \\ ${ }^{1}$ College of Bioscience and Biotechnology, Chubu University, Kasugai, Aichi, Japan \\ ${ }^{2}$ Section of Longitudinal Study of Aging, National Institute for Longevity Sciences (NILS-LSA), \\ National Center for Geriatrics and Gerontology, Obu, Aichi, Japan \\ ${ }^{3}$ Division of Liberal Arts and Sciences, Aichi Gakuin University, Nisshin, Aichi, Japan \\ ${ }^{4}$ Faculty of Health and Sport Sciences, University of Tsukuba, Tsukuba, Ibaraki, Japan \\ ${ }^{5}$ Faculty of Health and Medical Sciences, Aichi Shukutoku University, Nagakute, Aichi, Japan \\ ${ }^{6}$ Graduate School of Nutritional Sciences, Nagoya University of Arts and Sciences, Nisshin, Aichi, Japan
}

Received March 30, 2015; accepted July 20, 2015; released online November 28, 2015

Copyright (C 2015 Michiko Koda et al. This is an open access article distributed under the terms of Creative Commons Attribution License, which permits unrestricted use, distribution, and reproduction in any medium, provided the original author and source are credited.

\begin{abstract}
Background: Whether smokers and former smokers have worse lipid profiles or glucose levels than non-smokers remains unclear.

Methods: The subjects were 1152 Japanese males aged 42 to 81 years. The subjects were divided according to their smoking habits (nonsmokers, former smokers, and current smokers) and their visceral fat area (VFA) $\left(<100 \mathrm{~cm}^{2}\right.$ and $\geq 100 \mathrm{~cm}^{2}$ ).

Results: The serum triglyceride (TG) levels of 835 males were assessed. In the VFA $\geq 100 \mathrm{~cm}^{2}$ group, a significantly greater proportion of current smokers (47.3\%) exhibited TG levels of $\geq 150 \mathrm{mg} / \mathrm{dL}$ compared with former smokers (36.4\%) and non-smokers (18.8\%). The difference in TG level distribution between former smokers and non-smokers was also significant. However, among the subjects with VFA of $<100 \mathrm{~cm}^{2}$, the TG levels of the three smoking habit groups did not differ. The serum hemoglobin A1c (HbA1c) levels of 877 males were also assessed. In the VFA $<100 \mathrm{~cm}^{2}$ group, significantly higher proportions of current smokers $(17.9 \%)$ and former smokers (14.9\%) demonstrated HbAlc levels of $\geq 5.6 \%$ compared with non-smokers $(6.3 \%)$. In contrast, in the VFA $\geq 100 \mathrm{~cm}^{2}$ group, significantly fewer former smokers displayed $\mathrm{HbAlc}$ levels of $\geq 5.6 \%$ compared with non-smokers and current smokers. Furthermore, the interaction between smoking habits and VFA was associated with the subjects' TG and $\mathrm{HbA} 1 \mathrm{c}$ concentrations, and the associations of $\mathrm{TG}$ and $\mathrm{HbAlc}$ concentrations and smoking habits varied according to VFA.
\end{abstract}

Conclusions: Both smoking habits and VFA exhibited associations with TG and HbAlc concentrations. The associations between smoking habits and these parameters differed according to VFA.

Key words: smoking habits; visceral fat; interaction; serum triglycerides; hemoglobin A1c

\section{INTRODUCTION}

Smoking is a known risk factor for arteriosclerosis and diabetes mellitus (DM). Previous studies have reported that smokers have higher serum triglyceride (TG) and blood glucose concentrations and lower high-density lipoprotein cholesterol (HDL-C) concentrations than non-smokers. ${ }^{1-6}$ However, findings regarding whether smokers and former smokers have worse lipid profiles or glucose levels than non-smokers have been inconsistent. Freeman et al reported that smoking has little impact on TG levels in males. ${ }^{3}$ In addition, several studies have demonstrated that the insulin resistance and fasting serum glucose levels of current smokers and non-smokers do not differ significantly, ${ }^{7-10}$ and light smoking was found to reduce the risk of type $2 \mathrm{DM}$ in lean males. ${ }^{11}$ 
Differences in weight or fat distribution might have been responsible for the inconsistent results obtained by previous studies. Body weight and abdominal visceral fat (VF) volume are strongly associated with higher serum TG concentrations, ${ }^{12,13}$ lower serum HDL-C concentrations, ${ }^{14}$ and insulin resistance. ${ }^{15-17}$ In addition, smoking and/or smoking cessation might affect body weight and fat distribution. For example, many studies have indicated that smokers tend to have lower body weights than nonsmokers, ${ }^{18-20}$ and smoking cessation is known to be associated with substantial weight gain. ${ }^{20-22}$ It is also known that smoking is a risk factor for abdominal VF accumulation. ${ }^{19,23}$ Thus, the relationships among smoking, body weight, VF, serum lipids, and serum glucose levels are complex. Some previous studies have analyzed the associations of the interaction between smoking and body mass index (BMI) and lipid or glucose metabolism. ${ }^{11,24,25}$ However, BMI is not necessarily an accurate measure of VF accumulation, as it is influenced by both adipose and lean tissue.

Therefore, the purpose of this study was to investigate the interaction between smoking habits and VF area (VFA), which was measured using computerized tomography (CT) scans, and serum lipid (Study 1) or serum glucose (Study 2) concentrations.

\section{METHODS}

\section{Subjects}

The subjects were selected from among the 1152 Japanese males (age range, 40 to 82 years) who participated in the second wave of the National Institute for Longevity SciencesLongitudinal Study of Aging (NIL-LSA; the second wave examinations were conducted from April 2000 to May 2002). The NIL-LSA involved gender- and age-stratified samples that were randomly selected from the local neighborhood surrounding our institute. The purpose of the present study was explained to each subject before written consent was obtained. The design of the NILS-LSA has been described elsewhere. ${ }^{26}$ Subjects who had eaten breakfast were excluded. The smoking data and medical history of the subjects, including any medication and/or treatment that they had received, were self-reported by the subjects using a questionnaire. Non-smokers were defined as people that had never smoked. Former smokers were defined as those who had quit smoking more than 1 year ago and had not smoked since, and current smokers were defined as those who had been smoking for more than 1 year. The subjects of Study 1 were 835 males $(72 \%$ of the NIL-LSA cohort) who did not have a medical history of dyslipidemia and were not taking medication for the condition. The subjects of Study 2 were 877 males (76\% of the NIL-LSA cohort) who did not have a medical history of DM and were not taking medication for the condition (Figure 1).

\section{Measurements}

The subjects had their body weight $(\mathrm{kg})$ assessed in the morning after overnight fasting. Body weight was measured using digital scales with the subjects only wearing underwear. BMI was calculated as weight $(\mathrm{kg})$ divided by height $(\mathrm{m})$ squared. VFA $\left(\mathrm{cm}^{2}\right)$ and subcutaneous fat area (SFA; $\left.\mathrm{cm}^{2}\right)$ were measured using CT scans of the abdomen taken at the umbilical level (L4-L5). All CT scans (SCT-6800TX; Shimadzu, Osaka, Japan) were performed with the subjects in the supine position. VFA and SFA were calculated using computer software (Fat Scan; N2 Systems, Osaka, Japan) ${ }^{27}$ in accordance with a previously described procedure. ${ }^{28}$

Venous blood was collected in tubes containing ethylenediaminetetraacetic acid (EDTA, disodium salt, $50 \mathrm{mM}$ ) after overnight fasting, and then the samples' serum total cholesterol (TC; mg/dL), HDL-C (mg/dL), TG (mg/dL), glucose $(\mathrm{mg} / \mathrm{dL})$, and hemoglobin A1c (HbAlc) (\%) levels were analyzed. In this study, the HbAlc data are given in Japan Diabetes Society (JDS) units, which are calculated by subtracting 0.4 from standard HbA1c values. ${ }^{29}$

Dietary intake was estimated from 3-day food records, which were accompanied by before and after photos of each meal. ${ }^{30}$ Dietitians checked the food records while examining the photos. Physical activity was estimated from interviews regarding the subjects' physical activity in the past year. $^{31}$

\section{Data analysis}

The subjects were divided into three groups (non-smokers, former smokers, and current smokers) based on the results of the smoking habits questionnaire. In addition, the subjects were also grouped into two VFA categories (VFA $<100 \mathrm{~cm}^{2}$ and VFA $\geq 100 \mathrm{~cm}^{2}$ ), which were chosen based on the criterion for visceral obesity developed by the Japanese Society of Obesity. ${ }^{32}$ Comparisons of means among the smoking habit and VFA groups were performed using the Steel-Dwass test. Two-way ANOVA was used to evaluate the effects of the interaction between VFA categories and smoking habits on the subjects' serum concentrations of TG, HDL-C, TC, glucose, and HbAlc. Prior to the analysis, the subjects' HDL-C, TG, fasting glucose, and $\mathrm{HbA} 1 \mathrm{c}$ concentrations were converted to natural logarithms $(\ln )$ to normalize their skewed distributions. Comparisons between frequencies were performed using chisquared test. In Study 1, the following criteria were used to diagnose dyslipidemia: TC $\geq 220 \mathrm{mg} / \mathrm{dL}, \mathrm{HDL}-\mathrm{C}<40 \mathrm{mg} / \mathrm{dL}$, and $\mathrm{TG} \geq 150 \mathrm{mg} / \mathrm{dL}$. These criteria were developed by the Japan Atherosclerosis Society. ${ }^{33}$ In Study 2, the following criteria were employed to diagnose metabolic syndrome: fasting glucose $\geq 110 \mathrm{mg} / \mathrm{dL}$ and $\mathrm{HbA} 1 \mathrm{c}$ (JDS) $\geq 5.6 \%$. The former criteria were developed by the Japan Society of Obesity, ${ }^{32}$ and the latter criteria were used as a substitute for fasting glucose in the National Health and Nutrition Examination Survey. ${ }^{34}$ Probability values of less than 0.05 were regarded as significant. The data were analyzed using the 


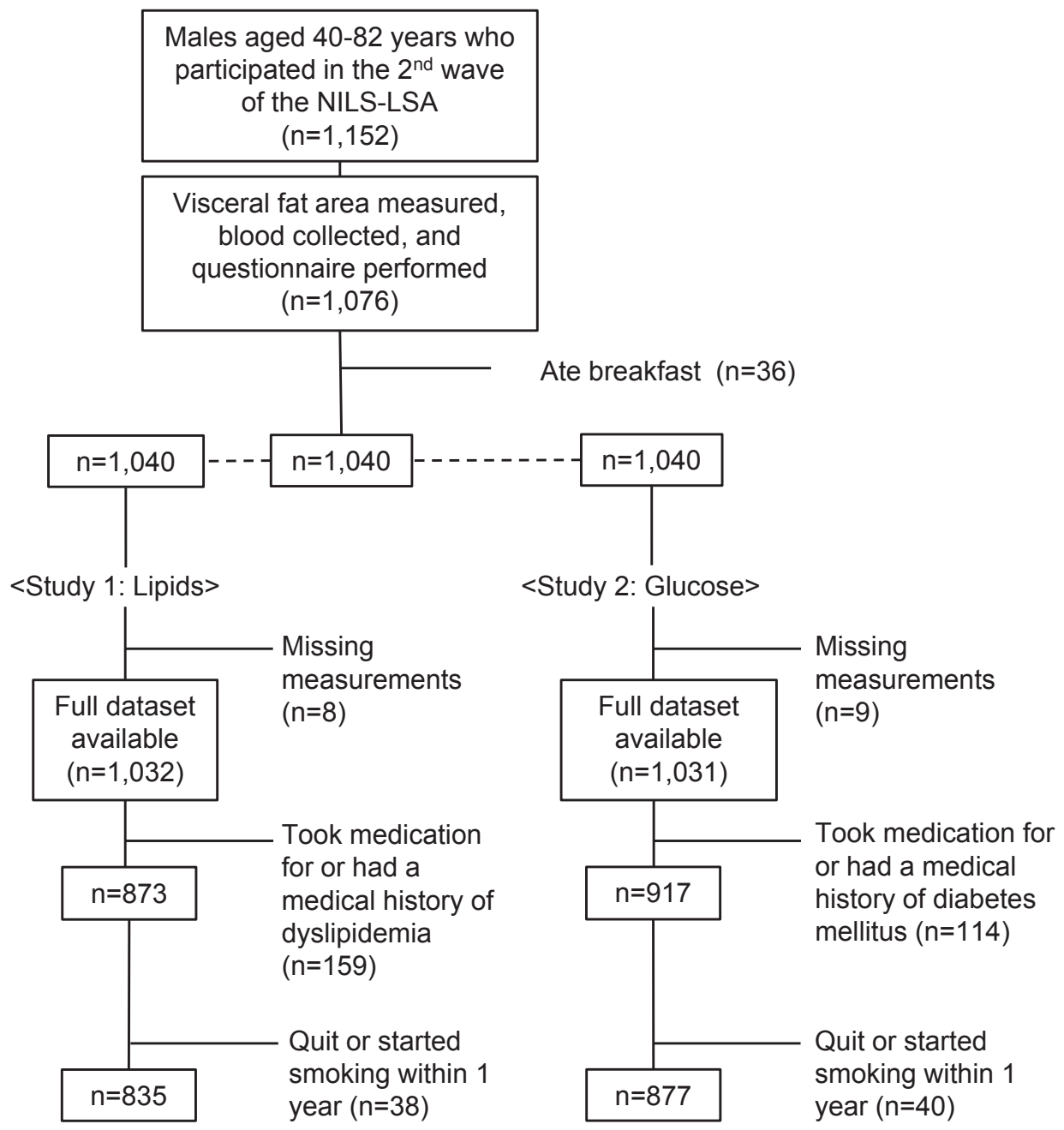

Figure 1. Sampling procedure.

SAS statistical software package (release 9.3; SAS Institute, Cary, NC, USA).

\section{Ethics}

This study was performed in accordance with the World Medical Association Declaration of Helsinki-Ethical Principles for Medical Research Involving Human Subjects. All of the procedures performed in the NILS-LSA were approved by the Committee of Ethics for Human Research at the National Center for Geriatrics and Gerontology. In the NILS-LSA study, an explanatory meeting was held 2 weeks before the start of the examinations. ${ }^{26}$ At the meeting, the purpose of the study and the procedures for each examination were fully explained to the subjects. All of the participants provided written informed consent. All data were analyzed collectively, and the subjects' privacy was protected.

\section{RESULTS}

\section{Study 1}

The characteristics of subjects in Study 1 are shown in Table 1. Compared with non-smokers $(22.8 \%)$ and current smokers $(30.0 \%)$, a significantly greater proportion of former smokers $(47.2 \%)$ exhibited VFA $\geq 100 \mathrm{~cm}^{2}(P<0.01)$. In the VFA $\geq 100 \mathrm{~cm}^{2}$ group, non-smokers had the lowest mean serum TG concentration $(P<0.01)$, and that of former smokers was significantly lower than that of current smokers $(P<0.01)$. Among subjects with VFA $<100 \mathrm{~cm}^{2}$, the serum TG levels of the three smoking habit groups did not differ, but current smokers had a significantly lower mean serum HDL-C concentration than former smokers $(P<0.05)$. In the VFA $\geq 100 \mathrm{~cm}^{2}$ group, the mean serum HDL-C concentration of current smokers was significantly lower than that of non-smokers $(P<0.01)$. The mean serum TC concentrations of the three smoking habit groups did not differ in either the VFA $<100 \mathrm{~cm}^{2}$ or VFA $\geq 100 \mathrm{~cm}^{2}$ groups. Similarly, energy intake and physical activity did not differ among the three smoking habit groups in either the VFA $<100 \mathrm{~cm}^{2}$ or VFA $\geq 100 \mathrm{~cm}^{2}$ group. Current smokers consumed more alcohol than the other groups.

Figure 2 shows the prevalence of elevated serum TC and TG levels and lower serum HDL-C concentrations. In the VFA $\geq 100 \mathrm{~cm}^{2}$ group, a significantly higher proportion of current smokers (47.3\%) exhibited serum TG levels 
Table 1. Characteristics of Study 1 subjects according to their smoking habits

\begin{tabular}{|c|c|c|c|c|c|c|c|}
\hline & \multirow{2}{*}{$\begin{array}{c}\text { All } \\
n=835\end{array}$} & \multicolumn{3}{|c|}{ VFA $<100 \mathrm{~cm}^{2}$} & \multicolumn{3}{|c|}{ VFA $\geq 100 \mathrm{~cm}^{2}$} \\
\hline & & $\begin{array}{c}\text { Non-smokers } \\
n=132\end{array}$ & $\begin{array}{c}\text { Former smokers } \\
\qquad n=193\end{array}$ & $\begin{array}{l}\text { Current smokers } \\
\qquad n=207\end{array}$ & $\begin{array}{c}\text { Non-smokers } \\
n=69\end{array}$ & $\begin{array}{c}\text { Former smokers } \\
\qquad n=143\end{array}$ & $\begin{array}{c}\text { Current smokers } \\
\qquad n=91\end{array}$ \\
\hline Age, years & $60.5(10.8)$ & $58.7(11.1)$ & $61.9(11.2)^{* *}$ & $58.7(10.5)^{\dagger \dagger}$ & $61.5(9.4)$ & $63.2(10.4)$ & $59.0(10.3)^{\dagger \dagger}$ \\
\hline $\mathrm{BMI}, \mathrm{kg} / \mathrm{m}^{2}$ & $22.9(2.8)$ & $21.9(2.3)$ & $21.9(2.4)$ & $21.3(2.3)^{* \dagger}$ & $25.1(2.1)$ & $25.0(2.4)$ & $24.8(2.4)$ \\
\hline VFA, $\mathrm{cm}^{2}$ & $90.2(49.8)$ & $57.9(24.9)$ & $61.9(24.5)$ & $59.9(25.5)$ & $137.8(30.6)$ & $144.4(40.7)$ & $144.4(35.8)$ \\
\hline Subcutaneous fat area, $\mathrm{cm}^{2}$ & $109.0(47.7)$ & $96.2(38.6)$ & $96.1(39.9)$ & $86.9(40.6)^{* \dagger}$ & $140.1(49.8)$ & $142.4(44.4)$ & $128.6(46.3)^{\dagger}$ \\
\hline Physical activity, METS*min/yr/10 3 & $701(876)$ & $709(88)$ & $700(90)$ & $713(98)$ & $701(71)$ & $680(70)$ & $691(82)$ \\
\hline Total cholesterol, mg/dL & $207.1(32.7)$ & $208.1(33.0)$ & $206.3(34.6)$ & $204.3(32.3)$ & 211.5 (33.9) & $210.2(29.9)$ & $205.3(32.1)$ \\
\hline $\mathrm{HDL}$ cholesterol, mg/dL & $57.9(14.9)$ & $61.7(13.5)$ & $62.4(16.3)$ & $58.7(16.1)^{\dagger}$ & $56.5(13.3)$ & $52.6(11.0)^{*}$ & $50.8(12.0)^{* *}$ \\
\hline \multirow[t]{2}{*}{ Triglycerides, mg/dL } & $120.6(71.2)$ & $110.9(53.7)$ & $101.8(48.0)$ & $112.0(63.1)$ & $111.4(39.9)$ & $143.3(78.5)^{* *}$ & $179.8(109.3)^{* * \dagger \dagger}$ \\
\hline & $n=777$ & $n=125$ & $n=180$ & $n=190$ & $n=64$ & $n=135$ & $n=83$ \\
\hline Energy intake, kcal & $2301(411)$ & $2318(414)$ & $2308(379)$ & $2270(408)$ & $2288(443)$ & $2279(387)$ & $2379(489)$ \\
\hline Alcohol intake, g/day & $16.5(20.3)$ & $15.9(19.0)$ & $15.9(19.2)^{*}$ & $18.6(23.0)^{* *}$ & $12.6(15.7)$ & $14.3(15.9)$ & $27.8(27.4)^{* * \dagger \dagger}$ \\
\hline
\end{tabular}

BMI, body mass index; HDL, high-density lipoprotein; METS, metabolic equivalents; VFA, visceral fat area.

Data are shown as mean (standard deviation) values.

The differences between groups were analyzed using the Steel-Dwass test.

$P$-values: Compared with non-smokers: ${ }^{*} P<0.05, * * P<0.01$; Compared with former smokers: ${ }^{\dagger} P<0.05,{ }^{\dagger \dagger} P<0.01$.

Total cholesterol $\geq 220 \mathrm{mg} / \mathrm{dL}$

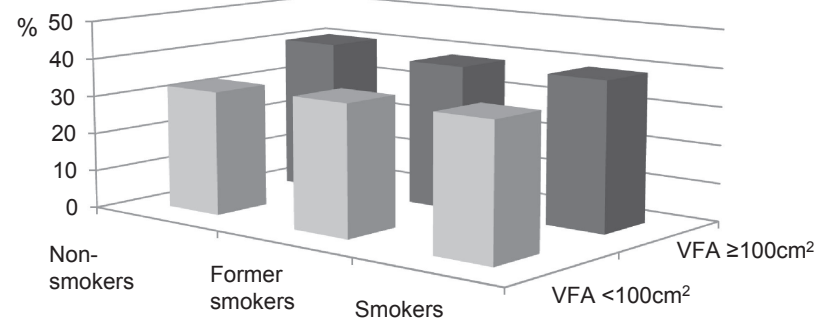

$\mathrm{HDL}$ cholesterol $<40 \mathrm{mg} / \mathrm{dL}$

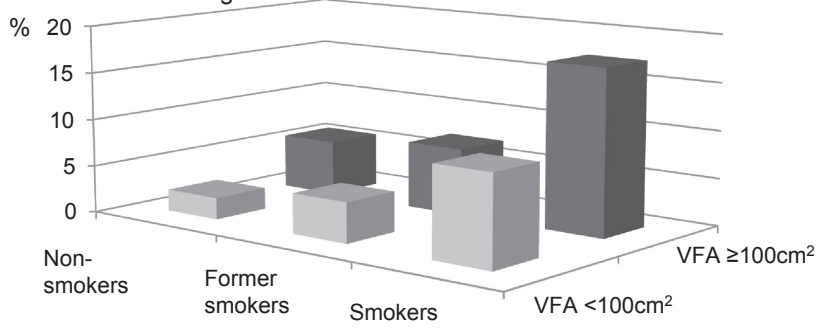

Triglycerides $\geq 150 \mathrm{mg} / \mathrm{dL}$

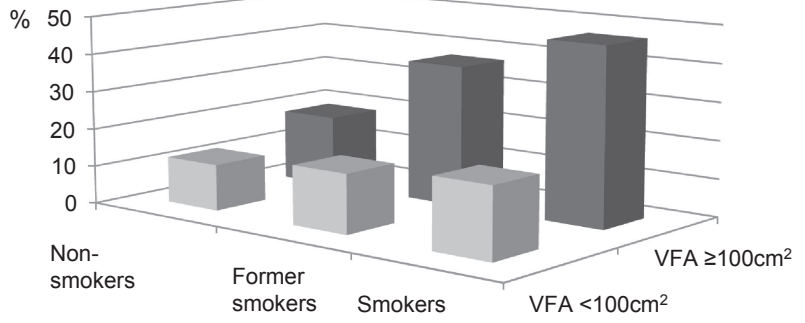

Figure 2. Frequencies of high serum total cholesterol and triglyceride levels and low serum HDL cholesterol concentrations.

$\geq 150 \mathrm{mg} / \mathrm{dL}$ compared with former smokers (36.4\%) and nonsmokers $(18.8 \%)$. In the VFA $<100 \mathrm{~cm}^{2}$ group, there was no difference in the frequency of serum TG levels $\geq 150 \mathrm{mg} / \mathrm{dL}$ among the three smoking habit groups. The frequency of serum HDL-C levels $<40 \mathrm{mg} / \mathrm{dL}$ was highest in current smokers in both the VFA $<100 \mathrm{~cm}^{2}$ (current smokers: $9.7 \%$,
Table 2. Two-way factorial ANOVA

\begin{tabular}{|c|c|c|c|c|}
\hline & & & F-value & $P$-value \\
\hline \multirow[t]{9}{*}{ Study 1} & In(Total cholesterol) & VFA & 1.67 & 0.197 \\
\hline & & smoking & 1.21 & 0.299 \\
\hline & & VFA*smoking & 0.21 & 0.812 \\
\hline & In(HDL cholesterol) & VFA & 60.49 & $<0.001$ \\
\hline & & smoking & 7.24 & $<0.001$ \\
\hline & & VFA*smoking & 1.14 & 0.320 \\
\hline & In(Triglycerides) & VFA & 96.52 & $<0.001$ \\
\hline & & smoking & 12.17 & $<0.001$ \\
\hline & & VFA*smoking & 5.53 & 0.004 \\
\hline \multirow[t]{6}{*}{ Study 2} & In(Glucose) & VFA & 40.16 & $<0.001$ \\
\hline & & smoking & 0.78 & 0.461 \\
\hline & & VFA*smoking & 5.75 & 0.003 \\
\hline & $\ln (\mathrm{HbA} 1 \mathrm{c})$ & VFA & 23.54 & $<0.001$ \\
\hline & & smoking & 5.91 & 0.003 \\
\hline & & VFA*smoking & 4.67 & 0.010 \\
\hline
\end{tabular}

ANOVA, analysis of variance; HDL, high-density lipoprotein; VFA, visceral fat area.

Two-way ANOVA was used to evaluate the effects of the interaction between VFA categories and smoking habits on the natural logarithms of the serum concentrations of total cholesterol, HDL cholesterol, triglycerides, glucose, and $\mathrm{HbA} 1 \mathrm{C}$.

former smokers: 3.6\%, non-smokers: 2.3\%) and VFA $\geq 100 \mathrm{~cm}^{2}$ groups (current smokers: $17.6 \%$, former smokers: 7.0\%, non-smokers: $5.8 \%$ ).

Two-way ANCOVA demonstrated that the interaction between VFA and smoking habits was significantly associated with the serum $\ln (\mathrm{TG})$ level but not serum $\ln (\mathrm{TC})$ or $\ln ($ HDL-C) levels (Table 2).

\section{Study 2}

The characteristics of subjects in Study 2 are shown in Table 3. Compared with non-smokers (33.3\%) and current smokers (35.5), a significantly greater proportion of former smokers (43.9\%) had VFA $\geq 100 \mathrm{~cm}^{2}(P<0.05)$. Non-smokers exhibited a significantly lower mean serum $\mathrm{HbAlc}$ level than 
Table 3. Characteristics of Study 2 subjects according to their smoking habits

\begin{tabular}{|c|c|c|c|c|c|c|c|}
\hline & \multirow{2}{*}{$\begin{array}{c}\text { All } \\
n=877\end{array}$} & \multicolumn{3}{|c|}{ VFA $<100 \mathrm{~cm}^{2}$} & \multicolumn{3}{|c|}{ VFA $\geq 100 \mathrm{~cm}^{2}$} \\
\hline & & $\begin{array}{c}\text { Non-smokers } \\
n=142\end{array}$ & $\begin{array}{c}\text { Former smokers } \\
\qquad n=202\end{array}$ & $\begin{array}{l}\text { Current smokers } \\
\qquad n=196\end{array}$ & $\begin{array}{c}\text { Non-smokers } \\
n=71\end{array}$ & $\begin{array}{c}\text { Former smokers } \\
\qquad n=158\end{array}$ & $\begin{array}{c}\text { Current smokers } \\
\quad n=108\end{array}$ \\
\hline Age, years & $60.3(10.7)$ & $58.8(10.9)$ & $61.2(11.2)^{*}$ & $58.7(10.7)^{\dagger}$ & $61.9(9.9)$ & $62.9(10.1)$ & $59.0(10.3)^{\dagger \dagger}$ \\
\hline $\mathrm{BMI}, \mathrm{kg} / \mathrm{m}^{2}$ & $23.0(2.8)$ & $22.0(2.2)$ & $22.1(2.3)$ & $21.3(2.4)^{* \dagger \dagger}$ & $25.2(2.1)$ & $25.0(2.3)$ & $25.0(2.3)$ \\
\hline VFA, $\mathrm{cm}^{2}$ & $91.4(49.7)$ & $57.3(24.0)$ & $63.3(24.1)^{*}$ & $58.4(25.4)^{\dagger}$ & $135.8(29.2)$ & $143.6(39.3)$ & $143.0(36.6)$ \\
\hline Subcutaneous fat area, $\mathrm{cm}^{2}$ & $111.5(47.7)$ & $95.1(36.4)$ & $99.2(40.0)$ & $87.5(40.7)^{\dagger \dagger}$ & $141.4(50.8)$ & $143.5(43.8)$ & $132.7(45.7)$ \\
\hline Physical activity, METS*min/yr $/ 10^{3}$ & $701(86)$ & $712(89)$ & $699(85)$ & $716(99)$ & $706(84)$ & $681(68)^{*}$ & $688(80)$ \\
\hline Glucose, mg/dL & $100.3(12.9)$ & $96.8(10.4)$ & $100.0(11.3)^{* *}$ & $97.5(11.1)^{\dagger}$ & $106.8(21.4)$ & $102.2(10.9)^{*}$ & $103.4(14.2)$ \\
\hline \multirow[t]{2}{*}{$\mathrm{HbA} 1 \mathrm{c}, \%$} & $5.22(0.49)$ & $5.05(0.40)$ & $5.17(0.38)^{*}$ & $5.23(0.46)^{* *}$ & $5.40(0.81)$ & $5.23(0.38)^{*}$ & $5.39(0.59)^{\dagger}$ \\
\hline & $n=816$ & $n=134$ & $n=190$ & $n=179$ & $n=65$ & $n=150$ & $n=98$ \\
\hline Energy intake, kcal & 2303 (401) & $2297(411)$ & 2309 (371) & 2298 (392) & $2279(432)$ & $2282(366)$ & $2359(485)$ \\
\hline Alcohol intake, g/day & $16.1(19.7)$ & $10.7(14.3)$ & $15.7(17.9)^{*}$ & $17.9(23.2)^{* *}$ & $12.3(15.5)$ & $14.6(15.8)$ & $25.4(26.2)^{* * \dagger \dagger}$ \\
\hline
\end{tabular}

BMI, body mass index; METS, metabolic equivalents; VFA, visceral fat area.

Data are shown as mean (standard deviation) values.

The differences between groups were analyzed using the Steel-Dwass test.

$P$-values: Compared with non-smokers: $* P<0.05, * * P<0.01$; Compared with former smokers: ${ }^{\dagger} P<0.05,{ }^{\dagger \dagger} P<0.01$.

Glucose $\geq 110 \mathrm{mg} / \mathrm{dL}$

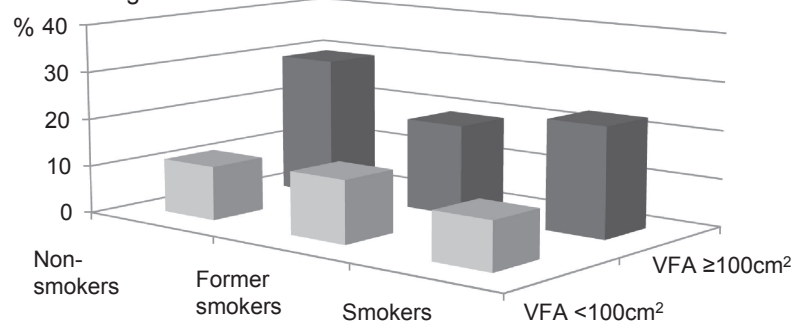

Hemoglobin A1c $\geq 5.6 \%$

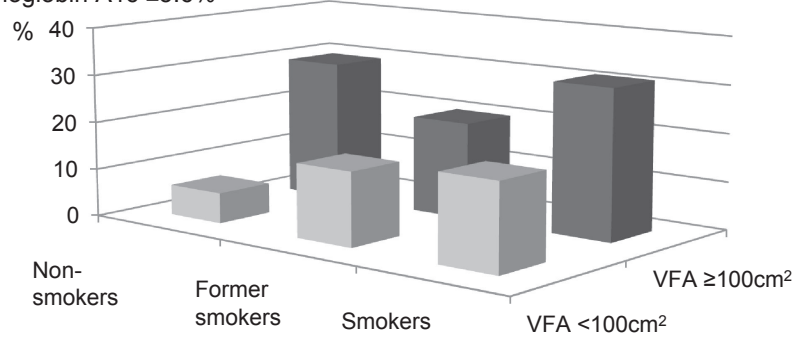

Figure 3. Frequencies of high serum glucose and hemoglobin A1c concentrations.

current smokers $(P<0.01)$ among the subjects with VFA $<100 \mathrm{~cm}^{2}$, whereas in the VFA $\geq 100 \mathrm{~cm}^{2}$ group, former smokers displayed a significantly lower mean $\mathrm{HbAlc}$ level than current smokers $(P<0.05)$. The mean serum glucose level was not associated with smoking habits in either the VFA $<100 \mathrm{~cm}^{2}$ or VFA $\geq 100 \mathrm{~cm}^{2}$ groups. Energy intake did not differ among the three smoking habit groups in the VFA $<100 \mathrm{~cm}^{2}$ or VFA $\geq 100 \mathrm{~cm}^{2}$ group. Current smokers consumed more alcohol than the other groups.

Figure 3 shows the prevalence of elevated glucose and HbA1c concentrations. In the VFA $<100 \mathrm{~cm}^{2}$ group, serum HbA1c levels of $\geq 5.6 \%$ were detected in significantly higher proportions of current smokers $(17.9 \%)$ and former smokers $(14.9 \%)$ than non-smokers $(6.3 \%)$, whereas in the VFA $\geq 100 \mathrm{~cm}^{2}$ group, serum HbAlc levels of $\geq 5.6 \%$ were observed in significantly greater proportions of current smokers $(31.5 \%)$ and non-smokers $(29.6 \%)$ than former smokers (19.6\%).

The relationships of the interaction between VFA and smoking habits and the subjects' serum glucose and HbAlc concentrations are shown in Table 3. Two-way ANCOVA demonstrated that the interaction between VFA and smoking habits was significantly associated with the subjects' serum $\ln$ (glucose) $(P=0.003)$ and $\ln (\mathrm{HbA} 1 \mathrm{c})$ levels $(P=0.010)$. However, no relationship was detected between the subjects' smoking habits and their serum glucose levels.

\section{DISCUSSION}

Our data showed that both smoking and VF accumulation were associated with serum TG, HDL-C, and $\mathrm{HbA} 1 \mathrm{c}$ concentrations, and that the interaction between smoking habits and VFA was also associated with serum TG and HbA1c levels but not serum HDL-C concentrations. The former two parameters demonstrated different relationships with the interaction between smoking habits and VFA, and the associations between smoking habits and these parameters differed according to VFA. The findings of the present study suggest that smoking is only weakly associated with the serum TG concentrations among men with little VF. However, in men with large amounts of VF, the relationship between smoking and serum TG concentrations might be stronger. Although smoking might be associated with HbA1c concentrations in men with little VF, it might not be as strongly related to HbAlc concentrations as VFA. Moreover, while the serum HDL-C level might be related to VFA, it may also be associated with smoking habits, irrespective of the amount of VF present.

These results suggest that differences in VF accumulation might have been responsible for the inconsistent results obtained by previous studies regarding the relationships between smoking and serum TG or HbAlc levels. Freeman 
et $\mathrm{al}^{3}$ reported that smoking had little impact on TG. However, the subjects of this study had a mean BMI of around $25 \mathrm{~kg} / \mathrm{m}^{2}$, so they probably did not have much VF. Some studies have found that the relationship between smoking and serum fasting glucose concentrations is stronger in lean men than in obese men. ${ }^{24,35,36}$ Our data support these findings. Henkin et $\mathrm{al}^{9}$ reported that there was no association between smoking and insulin sensitivity. The mean BMI of their participants was 29.4 (standard deviation, 5.9) $\mathrm{kg} / \mathrm{m}^{2}$; thus, it is presumed that most of the participants in their study were overweight or obese.

The mechanism responsible for the interaction between smoking habits and VF accumulation is poorly understood, although it seems to involve lipoprotein lipase (LPL) activity and certain adipocytokines. For example, the pre-heparin plasma LPL mass was found to be negatively correlated with TG concentration and insulin resistance and positively correlated with HDL-C concentration. ${ }^{37}$ Increased serum levels of adiponectin (an adipocytokine) have been found to be associated with higher HDL-C levels and lower $\mathrm{TG}^{38}$ and glucose concentrations. ${ }^{39}$

Abdominal VFA itself is strongly correlated with higher TG and lower HDL-C levels, as well as with insulin resistance. ${ }^{12,15-17}$ VF might release free fatty acids into the portal circulation, causing them to enter the liver directly, and excess free fatty acids might enhance hepatic TG synthesis and insulin resistance. ${ }^{38,40}$

However, smokers exhibit reduced plasma post-heparin LPL activity and adiponectin levels, ${ }^{41-43}$ and both of these parameters were found to be inversely correlated with VFA. ${ }^{37}$ We did not measure the serum levels of these substances, so further investigation of these relationships is required.

In the present study, about $35 \%$ of the subjects were smokers, which was similar to the prevalence obtained in the 2011 National Health and Nutrition Examination Survey $(32.4 \%){ }^{34}$

Energy balance is associated with body weight and VF accumulation, and physical activity improves serum lipid levels and insulin resistance. ${ }^{44,45}$ However, neither of these parameters differed among the three smoking habit groups in the present study. Smokers consumed more alcohol than nonsmokers in both the VFA $<100 \mathrm{~cm}^{2}$ and VFA $\geq 100 \mathrm{~cm}^{2}$ groups in the present study, and similar findings were obtained in previous studies. ${ }^{36,46,47}$ Alcohol consumption is also positively associated with serum HDL-C levels in both smokers and non-smokers, ${ }^{48,49}$ and excessive alcohol consumption is associated with higher serum TG concentrations. ${ }^{48,50}$ In the present study, we found that controlling for alcohol intake had little effect on our results (data not shown).

The current study had some limitations. First, we did not examine the number of cigarettes smoked per day or the duration since smoking cessation in our analysis, and the effects of smoking on serum lipid levels and $\mathrm{DM}^{2,11}$ have been shown to be dose-dependent. The number of years since smoking cessation has also been shown to be associated with the risk of DM. ${ }^{51-53}$ Thus, a longitudinal analysis examining the effects of the interaction between smoking and VF accumulation on serum lipid and glucose levels needs to be performed in the future. Second, passive smokers were not distinguished from non-smokers. It has been reported that passive smoking is associated with an increased risk of coronary heart disease ${ }^{54-56}$ and type $2 \mathrm{DM}^{57}$ and the nonsmoker group in the present study might have included some passive smokers.

In conclusion, smoking was found to be associated with higher serum TG, glucose, and HbA1c levels and lower serum HDL-C levels. The associations between smoking habits and these parameters differed according to VFA. However, the interaction between VFA and smoking habits exhibited different relationships with the serum levels of TG and HbAlc; VFA had a stronger association with serum HbA1c level than smoking, and, among subjects with a lot of VF, elevated serum TG levels were detected in significantly greater proportions of smokers and former smokers than nonsmokers. These findings suggest that not smoking and not accumulating VF are both important for health. In particular, middle-aged and elderly men with a lot of VF should not smoke or should quit smoking because smoking exhibits a strong adverse association with serum TG concentration.

\section{ONLINE ONLY MATERIAL}

Abstract in Japanese.

\section{ACKNOWLEDGMENTS}

We would like to thank the participants and our colleagues at the NILS-LSA. This study was supported by a Grant-in-Aid for Comprehensive Research on Aging and Health from the Ministry of Health, Labour and Welfare, Japan. This work was supported in part by research funding for Longevity Sciences from the National Center for Geriatrics and Gerontology, Japan (25-22).

Conflicts of interest: None declared.

\section{REFERENCES}

1. Håglin LM, Törnkvist B, Bäckman LO. High serum phosphate and triglyceride levels in smoking women and men with CVD risk and type 2 diabetes. Diabetol Metab Syndr. 2014;6(1):39. doi:10.1186/1758-5996-6-39.

2. Craig WY, Palomaki GE, Haddow JE. Cigarette smoking and serum lipid and lipoprotein concentrations: an analysis of published data. BMJ. 1989;298(6676):784-8.

3. Freeman DJ, Griffin BA, Murray E, Lindsay GM, Gaffney D, Packard CJ, et al. Smoking and plasma lipoproteins in man: effects on low density lipoprotein cholesterol levels and high density lipoprotein subfraction distribution. Eur J Clin Invest. 1993;23(10):630-40. 
4. Kuzuya M, Ando F, Iguchi A, Shimokata H. Effect of smoking habit on age-related changes in serum lipids: a cross-sectional and longitudinal analysis in a large Japanese cohort. Atherosclerosis. 2006;185(1):183-90.

5. Reaven G, Tsao PS. Insulin resistance and compensatory hyperinsulinemia: the key player between cigarette smoking and cardiovascular disease? J Am Coll Cardiol. 2003;41(6): 1044-7.

6. Houston TK, Person SD, Pletcher MJ, Liu K, Iribarren C, Kiefe CI. Active and passive smoking and development of glucose intolerance among young adults in a prospective cohort: CARDIA study. BMJ. 2006;332(7549):1064-9.

7. Wareham NJ, Ness EM, Byrne CD, Cox BD, Day NE, Hales $\mathrm{CN}$. Cigarette smoking is not associated with hyperinsulinemia: evidence against a causal relationship between smoking and insulin resistance. Metabolism. 1996;45(12):1551-6.

8. Soulimane S, Simon D, Herman WH, Lange C, Lee CM, Colagiuri $\mathrm{S}$, et al. HbA1c, fasting and $2 \mathrm{~h}$ plasma glucose in current, ex- and never-smokers: a meta-analysis. Diabetologia. 2014;57(1):30-9.

9. Henkin L, Zaccaro D, Haffner S, Karter A, Rewers M, Sholinsky $\mathrm{P}$, et al. Cigarette smoking, environmental tobacco smoke exposure and insulin sensitivity: the Insulin Resistance Atherosclerosis Study. Ann Epidemiol. 1999;9(5):290-6.

10. Masulli M, Riccardi G, Galasso R, Vaccaro O. Relationship between smoking habits and the features of the metabolic syndrome in a non-diabetic population. Nutr Metab Cardiovasc Dis. 2006;16(5):364-70.

11. Nagaya T, Yoshida H, Takahashi H, Kawai M. Heavy smoking raises risk for type 2 diabetes mellitus in obese men; but, light smoking reduces the risk in lean men: a follow-up study in Japan. Ann Epidemiol. 2008;18(2):113-8.

12. Fujioka S, Matsuzawa Y, Tokunaga K, Tarui S. Contribution of intra-abdominal fat accumulation to the impairment of glucose and lipid metabolism in human obesity. Metabolism. 1987;36(1): 54-9.

13. Taniguchi A, Nakai Y, Sakai M, Yoshii S, Hamanaka D, Hatae Y, et al. Relationship of regional adiposity to insulin resistance and serum triglyceride levels in nonobese Japanese type 2 diabetic patients. Metabolism. 2002;51(5):544-8.

14. Ross R, Aru J, Freeman J, Hudson R, Janssen I. Abdominal adiposity and insulin resistance in obese men. Am J Physiol Endocrinol Metab. 2002;282(3):E657-63.

15. Kobayashi H, Nakamura T, Miyaoka K, Nishida M, Funahashi $\mathrm{T}$, Yamashita $\mathrm{S}$, et al. Visceral fat accumulation contributes to insulin resistance, small-sized low-density lipoprotein, and progression of coronary artery disease in middle-aged non-obese Japanese men. Jpn Circ J. 2001;65(3):193-9.

16. Miyawaki T, Abe M, Yahata K, Kajiyama N, Katsuma H, Saito N. Contribution of visceral fat accumulation to the risk factors for atherosclerosis in non-obese Japanese. Intern Med. 2004; 43(12):1138-44.

17. Després JP, Couillard C, Gagnon J, Bergeron J, Leon AS, Rao $\mathrm{DC}$, et al. Race, visceral adipose tissue, plasma lipids, and lipoprotein lipase activity in men and women: the Health, Risk Factors, Exercise Training, and Genetics (HERITAGE) family study. Arterioscler Thromb Vasc Biol. 2000;20(8):1932-8.

18. Albanes D, Jones DY, Micozzi MS, Mattson ME. Associations between smoking and body weight in the US population: analysis of NHANES II. Am J Public Health. 1987;77(4): 439-44.

19. Shimokata H, Muller DC, Andres R. Studies in the distribution of body fat. III. Effects of cigarette smoking. JAMA. 1989; 261(8):1169-73.

20. Akbartabartoori M, Lean ME, Hankey CR. Relationships between cigarette smoking, body size and body shape. Int J Obes (Lond). 2005;29(2):236-43.

21. Carney RM, Goldberg AP. Weight gain after cessation of cigarette smoking. A possible role for adipose-tissue lipoprotein lipase. N Engl J Med. 1984;310(10):614-6.

22. Williamson DF, Madans J, Anda RF, Kleinman JC, Giovino GA, Byers T. Smoking cessation and severity of weight gain in a national cohort. N Engl J Med. 1991;324(11):739-45.

23. Mizuno O, Okamoto K, Sawada M, Mimura M, Watanabe T, Morishita T. Obesity and smoking: relationship with waist circumference and obesity-related disorders in men undergoing a health screening. J Atheroscler Thromb. 2005;12(4):199-204.

24. Komiya H, Mori Y, Yokose T, Tajima N. Smoking as a risk factor for visceral fat accumulation in Japanese men. Tohoku $\mathrm{J}$ Exp Med. 2006;208(2):123-32.

25. Katano S, Nakamura Y, Nakamura A, Murakami Y, Tanaka T, Nakagawa $\mathrm{H}$, et al. Relationship among physical activity, smoking, drinking and clustering of the metabolic syndrome diagnostic components. J Atheroscler Thromb. 2010;17(6): 644-50.

26. Shimokata H, Ando F, Niino N. A new comprehensive study on aging - the National Institute for Longevity Sciences, Longitudinal Study of Aging (NILS-LSA). J Epidemiol. 2000; 10 Suppl:S1-9.

27. Yoshizumi T, Nakamura T, Yamane M, Islam AH, Menju M, Yamasaki K, et al. Abdominal fat: standardized technique for measurement at CT. Radiology. 1999;211:283-6.

28. Okura T, Koda M, Ando F, Niino N, Shimokata H. Relationships of resting energy expenditure with body fat distribution and abdominal fatness in Japanese population. J Physiol Anthropol Appl Human Sci. 2003;22:47-52.

29. Seino Y. New diagnostic criteria for diabetes in Japan. Nihon Rinsho. 2010;68(12):2357-61 (in Japanese).

30. Imai $\mathrm{T}$, Sakai S, Mori K, Ando F, Niino N, Shimokata H. Nutritional assessments of 3-day dietary records in National Institute for Longevity Sciences-Longitudinal Study of Aging (NILS-LSA). J Epidemiol. 2000;10(1 Suppl):S70-6.

31. Kozakai R, Ando F, Kim HY, Rantanen T, Shimokata H. Regular exercise history as a predictor of exercise in communitydwelling older Japanese people. J Phys Fitness Sports Med. 2012;1(1):1-8.

32. Examination Committee of Criteria for 'Obesity Disease' in Japan; Japan Society for the Study of Obesity. New criteria for 'obesity disease' in Japan. Circ J. 2002;66(11):987-92.

33. Japan Atherosclerosis Society Guidelines for Prevention of Atherosclerotic Cardiovascular Diseases. 2007. Available: http://jas.umin.ac.jp/publications/pdf/guideline_summary.pdf (in Japanese).

34. National Health and Nutrition Examination Survey. 2011. Available: http://www.mhlw.go.jp/stf/houdou/2r9852000002q1statt/2r9852000002q1wo.pdf (in Japanese). 
35. Rimm EB, Chan J, Stampfer MJ, Colditz GA, Willett WC. Prospective study of cigarette smoking, alcohol use, and the risk of diabetes in men. BMJ. 1995;310(6979):555-9.

36. Nakanishi N, Nakamura K, Matsuo Y, Suzuki K, Tatara K. Cigarette smoking and risk for impaired fasting glucose and type 2 diabetes in middle-aged Japanese men. Ann Intern Med. 2000;133(3):183-91.

37. Kobayashi J, Saito K, Fukamachi I, Taira K, Takahashi K, Bujo $\mathrm{H}$, et al. Pre-heparin plasma lipoprotein lipase mass: correlation with intra-abdominal visceral fat accumulation. Horm Metab Res. 2001;33(7):412-6.

38. Cnop M, Havel PJ, Utzschneider KM, Carr DB, Sinha MK, Boyko EJ, et al. Relationship of adiponectin to body fat distribution, insulin sensitivity and plasma lipoproteins: evidence for independent roles of age and sex. Diabetologia. 2003;46(4): 459-69.

39. Ryo M, Nakamura T, Kihara S, Kumada M, Shibazaki S, Takahashi M, et al. Adiponectin as a biomarker of the metabolic syndrome. Circ J. 2004;68(11):975-81.

40. Matsuzawa Y, Nakamura T, Shimomura I, Kotani K. Visceral fat accumulation and cardiovascular disease. Obes Res. 1995;3 Suppl 5:645S-7S.

41. Freeman DJ, Caslake MJ, Griffin BA, Hinnie J, Tan CE, Watson $\mathrm{TD}$, et al. The effect of smoking on post-heparin lipoprotein and hepatic lipase, cholesteryl ester transfer protein and lecithin: cholesterol acyl transferase activities in human plasma. Eur J Clin Invest. 1998;28(7):584-91.

42. Kotani K, Hazama A, Hagimoto A, Saika K, Shigeta M, Katanoda K, et al. Adiponectin and smoking status: a systematic review. J Atheroscler Thromb. 2012;19(9):787-94.

43. Iwashima Y, Katsuya T, Ishikawa K, Kida I, Ohishi M, Horio T, et al. Association of hypoadiponectinemia with smoking habit in men. Hypertension. 2005;45(6):1094-100.

44. Marrugat J, Elosua R, Covas MI, Molina L, Rubiés-Prat J. Amount and intensity of physical activity, physical fitness, and serum lipids in men. The MARATHOM Investigators. Am J Epidemiol. 1996;143(6):562-9.

45. Donnelly JE, Blair SN, Jakicic JM, Manore MM, Rankin JW, Smith BK; American College of Sports Medicine. American College of Sports Medicine Position Stand. Appropriate physical activity intervention strategies for weight loss and prevention of weight regain for adults. Med Sci Sports Exerc. 2009;41(2): 459-71.
46. Gordon T, Doyle JT. Alcohol consumption and its relationship to smoking, weight, blood pressure, and blood lipids. The Albany Study. Arch Intern Med. 1986;146(2):262-5.

47. Chiolero A, Wietlisbach V, Ruffieux C, Paccaud F, Cornuz J. Clustering of risk behaviors with cigarette consumption: A population-based survey. Prev Med. 2006;42(5):348-53.

48. Wannamethee G, Shaper AG. Blood lipids: the relationship with alcohol intake, smoking, and body weight. J Epidemiol Community Health. 1992;46(3):197-202.

49. Gaziano JM, Buring JE, Breslow JL, Goldhaber SZ, Rosner B, VanDenburgh M, et al. Moderate alcohol intake, increased levels of high-density lipoprotein and its subfractions, and decreased risk of myocardial infarction. N Engl J Med. 1993;329(25): 1829-34.

50. Bessembinders K, Wielders J, van de Wiel A. Severe hypertriglyceridemia influenced by alcohol (SHIBA). Alcohol Alcohol. 2011;46(2):113-6.

51. Wannamethee SG, Shaper AG, Perry IJ; British Regional Heart Study. Smoking as a modifiable risk factor for type 2 diabetes in middle-aged men. Diabetes Care. 2001;24(9):1590-5.

52. Yeh HC, Duncan BB, Schmidt MI, Wang NY, Brancati FL. Smoking, smoking cessation, and risk for type 2 diabetes mellitus: a cohort study. Ann Intern Med. 2010;152(1):10-7.

53. Morimoto A, Ohno Y, Tatsumi Y, Nishigaki Y, Maejima F, Mizuno S, et al. Impact of smoking cessation on incidence of diabetes mellitus among overweight or normal-weight Japanese men. Diabetes Res Clin Pract. 2012;96(3):407-13.

54. Law MR, Morris JK, Wald NJ. Environmental tobacco smoke exposure and ischaemic heart disease: an evaluation of the evidence. BMJ. 1997;315:973-80.

55. He J, Vupputuri S, Allen K, Prerost MR, Hughes J, Whelton PK. Passive smoking and the risk of coronary heart disease metaanalysis of epidemiologic studies. N Engl J Med. 1999;340(12): 920-6.

56. Whincup PH, Gilg JA, Emberson JR, Jarvis MJ, Feyerabend C, Bryant A, et al. Passive smoking and risk of coronary heart disease and stroke: prospective study with cotinine measurement. BMJ. 2004;329:200-5.

57. Wang Y, Ji J, Liu YJ, Deng X, He QQ. Passive smoking and risk of type 2 diabetes: a meta-analysis of prospective cohort studies. PLoS One. 2013;8(7):e69915. doi:10.1371/journal. pone. 0069915 . 